\title{
溶質除去量測定によるダイアライザーの性能評価法
}

\author{
星 野敏久峰島三千男高橋 満彦江良和 雄 \\ 鈴木 利昭阿岸鉄三 杉野信博 太田和夫 \\ 東京女子医科大学腎藏病総合医療センター
}

(昭和 59 年 8 月 29 日受付)

key words：クリアランス，除去量測定法，赤血球膜抵抗，限外滤過流量，溶質除去速度

〈要旨〉

臨床におけるダイアライザーの性能評価法としては, クリアランス (CL), ダイアリザンス (DB) などが用いられて いる. これらの式中の血中濃度 $(C)$, 血液流量 $(\mathrm{Q})$ は全血基準として定義されているが, 溶質の種類によっては赤血 球内からの流出に対して移動抵抗が無視できないものと思われる.

本研究では, 透析液排液を一定時間（5 分）貯液し, 溶質除去速度を求める新しいダイアライザ一性能評価法を導 入し，溶質除去に及ぼす限外滤過流量および赤血球膜抵抗の影響について検討した。

その結果，尿素など低分子の蛋白代謝産物の除去速度は，限外濾過流量にほとんど影響されなかったものの，電解 質においては，拡散と限外濾過流量の影響が互いに無視できない関係にあった。

また，溶質除去に及ぼす赤血球膜抵抗の影響についてみると，尿素の赤血球内からの移動はきわめて速く，クリア ランスとしては従来の全血流量 $\left(\mathrm{Q}_{\mathrm{B}}\right)$ を用いてよいことが判明した. クレアチニンにおいては, 赤血球内からの流出 に移動抵抗がみられ，全血基準のクリアランスには問題があると思われた。尿酸では, ダイアライザー通過時間内で の赤血球内からの移動は無視できる程度であり, クリアランスとしては血漿流量 (QP) を用いるべきであると推察さ れた。

\section{Mass transfer performance in hemodialyzer by five-minute sampling of dialysate}

Toshihisa Hoshino, Michio Mineshima, Mitsuhiko Takahashi, Kazuo Era, Toshiaki Suzuki, M. D., Tetsuzo Agishi, M.D., Nobuhiro Sugino, M. D., Kazuo Ota, M. D.

Tokyo Women's Medical College, Kidney Center

This paper discusses the mass transfer performance in a hemodialyzer determined by a newly introduced method, which consists of five minute's sampling of the dialysate. By this method, the effects of convective flux and blood cell resistance on mass transport in a dialyzer were elucidated.

Removal dynamics of solutes such as urea, creatinine, uric acid, potassium and so on, which have a relatively large concentration difference between blood and dialysate, was strongly dependent on diffusion, but that of solutes with a relatively small concentration difference like sodium and chloride was depended on their interaction.

The urea and uric acid transfer rate through the blood cell membrane were higher and lower than that through the dialysis membrane, respectively. Therefore, clearance should be recorded as the whole blood and plasma flow rate for urea and uric acid, respectively. The creatinine transfer rate through those membranes cannot be neglected.

緒言

透析膜を介した溶質除去は，濃度差による拡散 （dif-

星野 敏久 東京女子医科大学腎臟病総合医療センター

于 162 新宿区市ヶ谷河田町 10 (03-353-8111) fusion) と限外濾過に伴う対流 (convection) の $2 つ の$ 物理現象によって支配されている。一方，臨床における ダイアライザーの性能評価法としては, 従来より次式の クリアランス (Ci) およびダイアリザンス (DB) が用い られている。 


$$
\begin{aligned}
& \mathrm{CL}_{\mathrm{L}}=\frac{\mathrm{CB}_{\mathrm{i}}-\mathrm{CB}_{\mathrm{o}}}{\mathrm{CB}_{\mathrm{i}}} \mathrm{QB} \\
& \mathrm{DB}=\frac{\mathrm{CB}_{1}-\mathrm{CB}_{0}}{\mathrm{CB}_{B_{1}}-\mathrm{CD}_{\mathrm{i}}} \mathrm{QB}
\end{aligned}
$$

(1)扔よび(2)式中の血中濃度 (C), 血液流量 (Q) は全血 を基準として定義されているが，溶質の種類によっては 赤血球の膜抵抗が無視できないと思われる。

このような観点から本研究では，透析液の排液を約 5 分間貯液することにより溶質除去速度を求め, 溶質除去 に及ぼす限外濾過流量と赤血球膜抵抗の影響について検 討したところ若干の知見がえられたので報告する。

\section{対象・方法}

本研究で測定した血中濃度（C）は，赤血球内からの 溶質の流出による影響を避けるため, 採血後ただちに遠 心分離を施した血漿の濃度 (CP) として表わした。

従来より全血流量 $(\mathrm{QB})$ が用いられている全血を基準 とした溶質除去速度 (mB) およびクリアランス (CLB) は，(3)，(4)式として算出できる. 同様に血漿流量 (QP) を 用いた血獎基準の溶質除去速度 $(\dot{\mathrm{mP}})$ およびクリアラン ス (CLP) は，(5)，(6)式のごとく表わされる.な拈血漿流 量は(7)式により求めた。

$$
\begin{aligned}
& \dot{\mathrm{mB}}=\mathrm{QB}_{1} \cdot \mathrm{CP}_{1}-\mathrm{QB}_{\mathrm{O}} \cdot \mathrm{CP}_{\mathrm{O}} \\
& \mathrm{CLB}=\frac{\dot{\mathrm{mB}}}{\mathrm{CP}_{1}} \\
& \dot{\mathrm{mP}}=\mathrm{QP}_{1} \cdot \mathrm{CP}_{1}-\mathrm{QP}_{\mathrm{O}} \cdot \mathrm{CP}_{\mathrm{O}} \\
& \mathrm{CLP}=\frac{\dot{\mathrm{mP}}}{\mathrm{CP}_{1}} \\
& \mathrm{QP}=\mathrm{QB}(1-\mathrm{Ht})
\end{aligned}
$$

図 1 は, 今回われわれが導入した除去量測定法のフ ローダイアグラムを示したものである，正確な限外滤過 流量を把握するため, 患者監視装置には限外滤過制御機 能を有する東レ社製の UFR コントローラーを用い，排 液の貯液時間を 5 分と定めた。

透析液側より一定時間 (TA) にダイアライザーより除 去される溶質除去速度 $(\dot{\mathrm{m} D})$ は, 排液と限外濾過量をあ わせた貯液量を(VA) とすると(8)式を用いて推算するこ

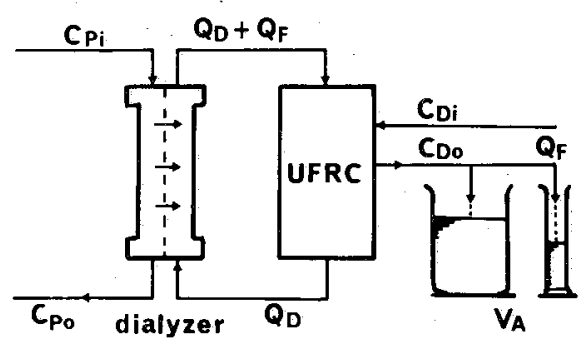

図 1 溶質除去量測定法のフローダイアグラム

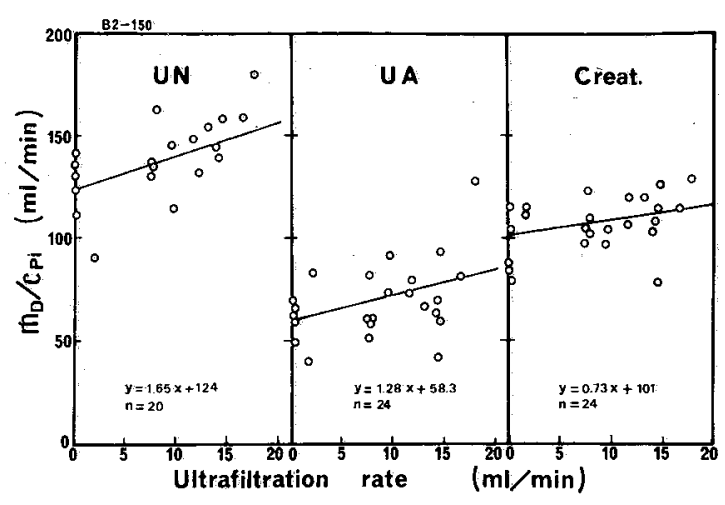

図 2 溶質除去に及ぼす限外濾過流量の影響（尿素，尿 酸, クレアチニン)

とが可能である.またクリアランス (CLD) は(9)式から算 出することができる。

$$
\begin{aligned}
& \dot{\mathrm{mD}}=\left(\mathrm{VA} \cdot \mathrm{CD}_{\mathrm{O}}-\mathrm{QD} \cdot \mathrm{CD}_{\mathrm{i}} \cdot \mathrm{TA}\right) / \mathrm{TA}_{\mathrm{A}} \\
& \mathrm{CLD}=\frac{\dot{\mathrm{mD}}}{\mathrm{CP}_{\mathrm{i}}}
\end{aligned}
$$

対象患者は，われわれの施設にて慢性腎不全の治療を うけている男性 3 名, 女性 4 名である. 測定条件は透析 開始 1 時間後, 透析液流量 500 , 血液流量を $200 \mathrm{ml} / \mathrm{min}$ とし限外濾過流量を $0 \sim 20 \mathrm{ml} / \mathrm{min}$ の範囲内に設定し, 定常状態になるまで 10 分間以上待ったのちサンプルの 採集を開始した。

測定項目は尿素，クレアチニン，尿酸， $\mathrm{Na}, \mathrm{K}, \mathrm{Cl}, \mathrm{P}$ であり,使用したダイアライザーは, 東レ社製の B 2-150 $\left(1.2 \mathrm{~m}^{2}\right)$ である。

\section{結果・考察}

\section{1. 限外滤過流量の影響}

図 2 は除去量測定法によって求めた尿素，クレアチニ ン, 尿酸の限外濾過流量に対するクリアランス (CLD) を プロットしたものである. 直線回帰の Y 軸の切片は拡散 による除去速度を示し，傾きは限外滤過流量の影響を表 わしている。

限外濾過流量が $0 \mathrm{ml} / \mathrm{min}$ における尿素の CLD は 124 $\mathrm{m} l / \mathrm{min}$ であり, 限外濾過流量が $20 \mathrm{ml} / \mathrm{min}$ では 157 $\mathrm{m} l / \mathrm{min}$ となり，多少増加傾向がみられたものの注とん ど拡散支配性であることがわかる。また尿酸, クレアチ ニンも同様の結果をえた.

図 3 は除去量測定法による電解質のクリアランス (CLD) を求めたものである. Na の CLD は限外濾過流 量が $0 \mathrm{ml} / \mathrm{min}$ において $3.74 \mathrm{ml} / \mathrm{min}$ と小さく, 拡散の 影響は少なかった。しかし限外滤過流量が $20 \mathrm{~m} l / \mathrm{min} に$ 上昇すると CLD は $14.3 \mathrm{~m} l / \mathrm{min}$ と増大し, 限外濾過流 量に大きく依存していた。また $\mathrm{Cl}$ は $\mathrm{Na}$ と同じような傾 


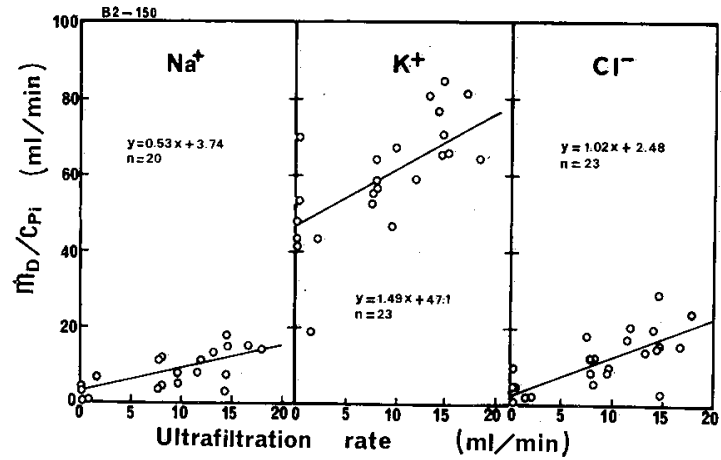

図 3 溶質除去に及ぼす限外濾過流量の影響（電解質）

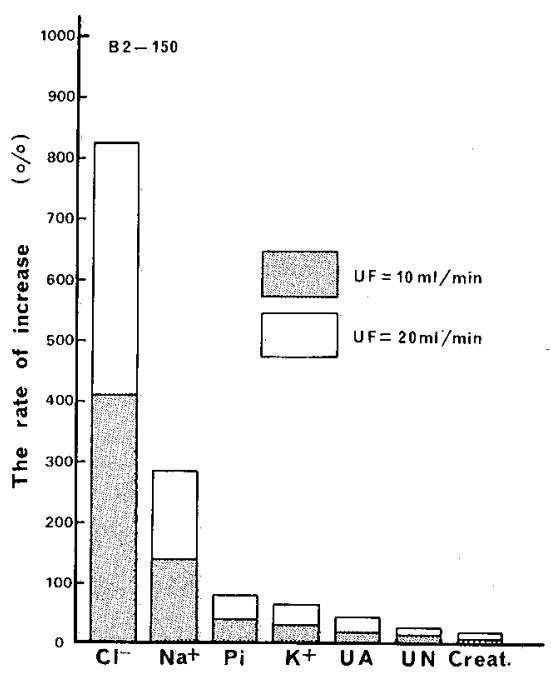

図 4 各溶質の限外滤過流量が $0 \mathrm{~m} l / \mathrm{min}$ に対するクリ アランス $\left(\mathrm{C}_{\mathrm{LD}}\right)$ の増加率
向を示した，Kに関しては図のように $\mathrm{Y}$ 軸の切片が大き くなり, 限外濾過流量と拡散の両者に支配されているこ とが理解される。

図 4 は各溶質の限外腹過流量が $0 \mathrm{ml} / \mathrm{min}$ に対して $10,20 \mathrm{~m} l / \mathrm{min}$ に増加させたときの CLD の増加率をパー セントで表わしたものである. $\mathrm{Na}, \mathrm{Cl}$ は限外濾過流量の 上昇に伴い大幅な増加を示したが, $\mathrm{P}, \mathrm{K}$ については急激 な増加傾向を示さず, 拡散と限外濾過流量の両者に支配 されている。また尿素, クレアチニン，尿酸の増加率は 電解質に比較して低值を示した。

このような結果から各溶質の除去速度は透析液濃度に 強く依存しており, 尿素などの低分子の蛋白代謝産物に おいては透析液濃度が 0 であるため, 拡散支配性が強く 表われたものと思われる，しかし $\mathrm{Na}$ な゙生体の恒常性 を維持している電解質では, 透析液濃度を血中濃度に近 接させているため, 拡散と限外滤過流量の影響が互いに 無視できない関係にあった。したがって，電解質におい ては除水量が異なれば除去量も異なることになり, 限外 濾過流量の影響が大きい点を十分考慮すべきと考えられ る.

\section{2. 赤血球膜抵抗の影響}

図 5 は尿素, クレアチニン，尿酸に及ぼす赤血球膜抵 抗の影響について調べたものであり，本法による除去速 度 $\dot{\mathrm{mD}}$ に対する全血基準の $\dot{\mathrm{mB}}$ および血漿基準の $\dot{\mathrm{mP}}$ プロットしたものである.

尿素の $\dot{\mathrm{mB}}$ は傾き 1 の点線上にプロットされているの に対し, $\dot{\mathrm{mP}}$ は $\dot{\mathrm{mD}}$ よりかなり低值を示した。 またりレ アチニンの $\dot{\mathrm{mB}}$ は $\dot{\mathrm{mD}}$ より多少大きい值となり, $\dot{\mathrm{mP}}$ は 尿素に比較し $\dot{M} \mathrm{D} に$ 近似したプロットがえられた。尿酸 についてみるとクレアチニンと同様であるがその傾向は 強く表われていた。

図 6 はへマトクリット值をX軸にとり, 除去量測定法 によるクリアランス CLD および血漿基集のクリアラン
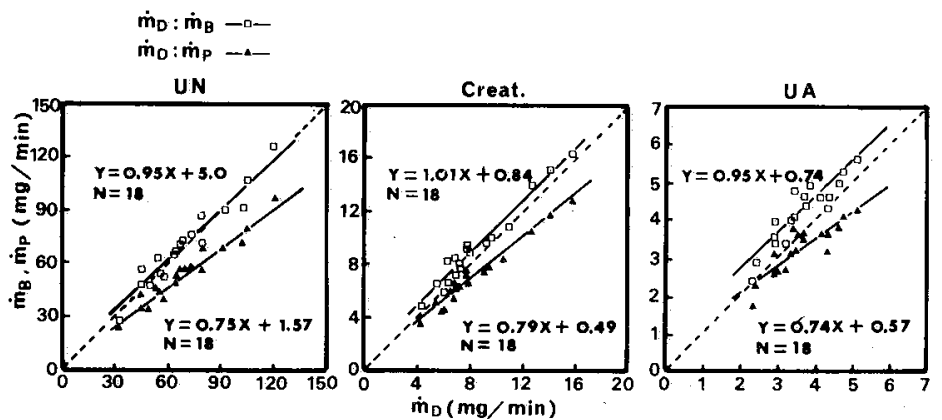

図 5 溶質除去量測定法による除去速度 $\left(\dot{\mathrm{m}}_{\mathrm{D}}\right)$ に対する 全血基準の除去速度 $\left(\dot{m}_{\mathrm{B}}\right)$ および血漿基準の除去 速度 $\left(\dot{m}_{\mathrm{P}}\right)$ 


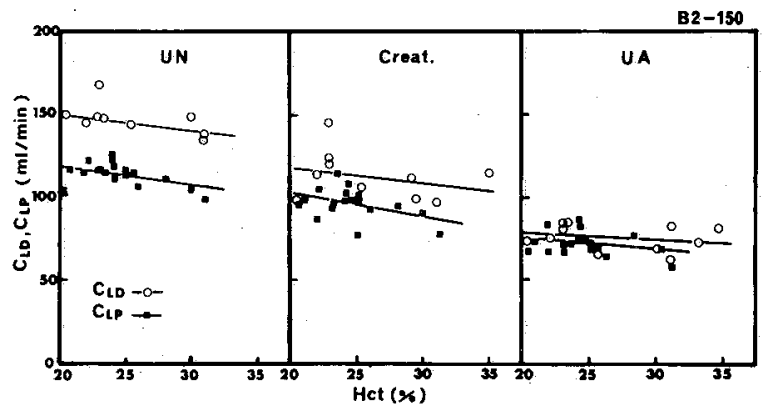

図6 ヘマトクリット値に対する溶質除去量測定法によ るクリアランス $\left(\mathrm{C}_{\mathrm{LD}}\right)$ と血漿基準のクリアラン ス $\left(\mathrm{C}_{\mathrm{LP}}\right)$ の比較

スCLPをプロットし比較したものである.なおクリアラ ンスの測定は限外滤過流量を $0 \mathrm{ml} / \mathrm{min}$ として実施し た。

尿素の CLP は CLD より $30 \mathrm{ml} / \mathrm{min}$ ほど低值を示し， クレアチニンの CLP は尿素と比較して CLD に近似した 值となった。また尿酸についてみると，CLD と CLP は ほぼ同一線上にプロットされた。

図 5,6の結果より尿素に対する赤血球膜抵抗の影響は ほとんどなく, 全血基準の溶質除去速度 $\mathrm{mB}$ と除去量測 定法による $\mathrm{mD}$ は同一の值を示した。 クリアランスとし ては，血漿流量 QP をかけるとみかけ上低值を示してし まい，従来より用いられている全血基準のクリアランス を適用してよいことがわかる。

クレアチニンに枕いては, 赤血球内からの流出に多少 移動抵抗がみられ, 尿素と比較して $\dot{\mathrm{mP}}$ は $\dot{\mathrm{mD}}$ に近づき, また血漿流量をかけているクリアランス CLP は, CLD に 近似した値を示すことになった。

尿酸ではダイアライザー通過時間内での赤血球内から の流出がほとんどなく，除去された尿酸の大部分は血獎 中のものであり, 全血流量をかけている $\mathrm{mB}$ はかけ上 大きい值となってしまう。一方，血漿流量をかけている CLP は CLD と同一線上にプロットされている.したがっ て尿酸においては，従来の全血基準のクリアランスを適 用できず，血漿基準のクリアランスを用いる心゙きである と推測された。

\section{結論}

1）溶質除去に及ぼす限外滤過流量の影響は，尿素な どの低分子の蛋白代謝産物ではほとんどみられず，電解 質においては拡散と限外濾過流量の影響が互いに無視で きない関係にあった。

2 ）尿素の赤血球内からの移動はきわめて速く, 全血 基準のクリアランスは適用可能であった。
3) クレアチニンは赤血球内からの流出に移動抵抗が みられ，従来の全血基準のクリアランスには問題がある と思われた。

4) 尿酸では，ダイアライザー通過時間内での赤血球 内からの移動は無視できる程度であり,クリアランスと しては血漿流量を用いるべきである。

除去量測定法は，実際に透析膜より除去された溶質を 測定することにより，除去速度を推算することが可能で あり， $\mathrm{mD} / \mathrm{CP}_{1}$ はダイアライザーの性能評価を行うにあ たって有用な指標であることが判明した。

\begin{tabular}{ll}
\multicolumn{2}{c}{ 使用記号 } \\
$\mathrm{C}:$ 濃度 & $(\mathrm{mg} / \mathrm{d} l)(\mathrm{mEq} / l)$ \\
$\mathrm{CL}:$ クリアランス & $(\mathrm{m} l / \mathrm{min})$ \\
$\mathrm{DB}:$ ダイアリザンス & $(\mathrm{m} l / \mathrm{min})$ \\
$\mathrm{Ht}:$ ヘマトクリット & $(\%)$ \\
$\dot{\mathrm{m}}:$ 除去速度 & $(\mathrm{mg} / \mathrm{min})(\mathrm{mEq} / \mathrm{min})$ \\
$\mathrm{Q}:$ 流量 & $(\mathrm{m} l / \mathrm{min})$ \\
$\mathrm{TA}:$ 貯液時間 & $(\mathrm{min})$ \\
$\mathrm{VA}:$ 貯液量 & $(\mathrm{m} l)$ \\
\hline
\end{tabular}

添字
B：血液
i : 入口
$\mathrm{D}$ : 透析液
$\mathrm{O}$ : 出口
$\mathrm{P}$ ：血獎

\section{文献}

1）酒井清孝，峰島三干男，石川厚史：血液浄化療法に おける Kinetics. 人工臟器, $10(3): 766-773,1981$.

2) 峰島三千男, 日比政昭, 板垣一郎, 酒井清孝, 鈴木 満, 井上政昭, 中西 光, 神谷勝弘: 血液透析にお けるUremic Toxin の除去性能.人工臟器, 8 (6) : 698-701, 1979.

3）新井信之, 竹沢真吾, 酒井清孝：ダイアライザーの 性能評価に乩ける牛血使用の問題点. 人工臟器, 10 ( 3 ) : 664-667, 1984.

4）山下明泰, 吉本達雄, 善本勝男, 白石幸次, 酒井 絊, 酒井清孝：溶質の除去量測定に関する方法論的考 察。透析会誌, 15(6)：803-807，1982.

5）峰島三千男，山下明泰，酒井清孝：血漿濃度，除去 量, クリアランスによる評価法の差異一HD vs. HF 一. 人工臟器, $12(1): 41-44,1983$.

6）星野敏久, 峰島三千男, 高橋満彦, 島田浩通, 江良 和雄, 鈴木利昭, 阿岸鉄三, 杉野信博, 太田和夫 : ダイアライザー内物質移動に及ぼす限外濾過流束の 影響. 東京透析懇談会 (1984)，投稿中. 